Faculty of Law, University of Belgrade

UDK: 339.922(410:4-672EU)

Рад примљен: 05.10.2020.

Рад прихваћен: 09.12.2020.

\title{
WITHDRAWAL FROM THE EUROPEAN UNION: CONSEQUENCES UNDER EU LAW AND INTERNATIONAL LAW
}

\begin{abstract}
This article provides analysis of the most prominent legal issues arising as a consequence of a voluntary withdrawal of a Member State from the European Union pursuant to Article 50 TEU. Particular attention is given to the aspects which have not been explicitly regulated, as well as to those that remain unclear due to the complex wording of Article 50 TEU. Following the introduction, the first section focuses on the termination of application of EU law. The second section provides a more detailed insight into the consequences of the voluntary withdrawal on the issues related to the EU citizenship. The next section elaborates on the legal framework for establishing relations between the withdrawing state and the EU under international law. Finally, the last section of the paper analyzes the consequences for the position of the withdrawing state vis-à-vis international organizations and under international law in general.
\end{abstract}

Keywords: voluntary withdrawal from the EU, Article 50 TEU, Withdrawal Agreement, EU law, EU citizenship, external relations of the State withdrawing from the $E U$.

\section{Introduction}

Withdrawal of a Member State from the European Union (EU) seems to be a phenomenon which is rather unexpected and difficult to grasp from the standpoint of the concept of the EU as an "ever closer union", which is the only conceptual definition of the EU that can be found in the founding treaties. Over the course of seven decades, the ties between the Community and EU member states have continually grown stronger, involving a gradually increasing transfer of sover-

*maja.lukic@ius.bg.ac.rs 
eign powers to the Union and creating an entity that is today perceived even as possessing certain attributes of sovereignty. ${ }^{1}$

Nowadays, when withdrawal from the EU is mentioned, the first thing that comes to one's mind is the so-called "Brexit" - the withdrawal of the United Kingdom from the EU following the UK membership referendum which took place on 23 June 2016. Brexit is the first association not only because it is the first ever withdrawal of a state from the EU but also due to the highly contentious way in which it has unfolded thus far.

The subject matter of the paper is not Brexit per se, but legal regulation of withdrawal from the EU in general, which shall be analysed from several perspectives. The first perspective entails the issue of cessation of effectiveness of EU law. The second one pertains to the consequences of withdrawal of a Member State upon citizenship-related rights and obligations of individuals. The third one refers to the establishment of the legal framework for relations between the withdrawing state and the $\mathrm{EU}$, and the fourth one analyses the consequences of withdrawal under international law.

The first three enumerated perspectives assume two principal steps, both of which may but do not need to be undertaken in each particular situation: the first is the conclusion and performance of a withdrawal agreement, while the second is the conclusion and performance of an agreement on relations between the EU and the withdrawing state following the withdrawal.

According to Article 50 of the Treaty on the European Union (TEU) ${ }^{2}$, EU law shall cease to apply after two years from the notification on withdrawal by the withdrawing state, unless it is otherwise stipulated by the withdrawal agreement.

The unfolding of Brexit permeates the analysis that shall be presented in this paper, not only because it represents the first ever withdrawal of a Member State from the European Union but also due to the fact that its generally contentious unfolding has already generated an abundance of research material.

Finally, withdrawal from the European Union should be differentiated from a possible withdrawal of a country from the Euro area. Presently, the Euro area is composed of nineteen EU Member States, out of the total of twenty-seven states. Since the adoption of Euro comprises a substantially greater level of coordination and harmonization of economic policy and specific legal and institutional arrangements (Dashwood, 2013: 741-745), a possible withdrawal from the Eu-

1 For a specific discussion on the approximation of sovereignty in the form of constitutionalization of the EU, see: Lukić, 2015.

2 TEU - Treaty on the European Union. Consolidated version of the Treaty on European Union OJ C 326, 26.10.2012, p. 13-390 
rozone would entail considerable legal and political issues. In contrast to the withdrawal from the EU, withdrawal from the Eurozone has not been regulated in advance by the EU treaties or by any other instrument.

\section{Termination of application of EU law}

\subsection{Article 50 TEU}

Article 50 TEU was introduced in primary EU law in 2009, by virtue of the Lisbon Treaty. It sets forth the only legal mechanism for a Member State to withdraw from the EU. Opinions of academics are divided on the question whether the right to withdraw from the Union had existed under general international law prior to the inclusion of Article 50. ${ }^{3}$ According to Wyrozumska (2012), such a right had not existed due to the specific contents of the founding treaties, so that inclusion Art. 50 TEU marked a substantial change in the overall institutional nature and structure of the Union (Wyrozumska, 2012: 362-363).

The basic structure of the mechanism is the following: after the withdrawing state files a notification on withdrawal, either a withdrawal agreement may be concluded between the Union and such state, or the effect of EU law in relation to that state ceases after expiry of two years. The transition period is an inevitable step, and may either be regulated by the withdrawal agreement, or, if such agreement is not concluded, the transition period lasts for two years following the withdrawal notification by virtue of Article 50(3) of the TEU.

In relation to the withdrawal agreement, Art. 50(2) TEU explicitly refers to the procedure for negotiating agreements between the Union and third countries or international organizations, set forth in Article 218(3) TFEU. Article 50 TEU supplements Article 218 TFEU by requiring the consent of the European Parliament for conclusion of the withdrawal agreement, thus expanding the list of situations for which such consent is required in accordance with Art. 218(6) (a) TFEU. As any other agreement with a third country or an international organization, the withdrawal agreement is concluded on behalf of the Union by the Council, deciding by the higher of the two thresholds for qualified majority provided in Article 238(3) TFEU - the one applicable to proposals that do not come either from the Commission or the High Representative of the Union for Foreign Affairs and Security Policy.

3 For an overview of mutually opposed opinions on the subject, see: Wyrozumska, 2012.

4 TFEU - Treaty on the Functioning of the European Union. Consolidated version of the Treaty on the Functioning of the European Union OJ C 326, 26.10.2012, pp. 47-390. 
By stipulating the same competence and procedure for conclusion of the withdrawal agreement as for the agreements between the Union and third countries or international organizations, Article 50 clearly assumes that, starting from the moment the notification of withdrawal is filed by the withdrawing state, such state needs to be deemed to have interests different from those of the EU and not different from those of any other third country, so that interests of the EU in relation to such country need to be protected accordingly.

\subsubsection{Is the withdrawal notification revocable?}

Academic literature diverges in respect of the question of whether the withdrawal notification is revocable during the transition period. Perakis (2018) argued in favor of irrevocability of the withdrawal notification; he based his view on the interpretation of Article 50 TEU, citing both the wording thereof, the reference to Article 218(3) TFEU as well as the drafting history of the text, i.e. the fact that inclusion of explicit possibility of revocation of said notification was indeed discussed and rejected. He rejects the claim that the possibility of revocation may be based on the Vienna Convention on the Law of Treaties and customary international law by citing the principle of autonomy of EU law (Perakis, 2018). ${ }^{5}$ A contrary interpretation has been offered, among others, by Craig, who based his view on the textual meaning of the provisions of Article 50(3) TEU and Article 50(1) TEU. According to his opinion, the fact that during the transition period the withdrawing state may conclude a withdrawal agreement also means that it may revoke the notification and abandon withdrawal negotiations altogether, in accordance with its own constitutional requirements (Craig, 2016: 34-35). Benrath argues in favour of revocability of withdrawal notification by rebutting the claim that revocation and re-notification may be abused. According to his interpretation of Art. 50 TEU, the European Council may interpret any revocation, as well as re-notification, in line with the principle of good faith; thus, a revocation of withdrawal issued contrary to that principle may simply be deemed void by the European Council (Benrath, 2018: 247).

The Court of Justice of the European Union (CJEU) affirmed the view that the revocation was indeed allowed, provided that it is issued prior to entry into force of a possible withdrawal agreement or, if such agreement remains absent, prior to the expiry of the two-year default transition period. ${ }^{6}$ The CJEU issued this opinion pursuant to a reference for preliminary ruling procedure, upon the request of the Scottish Inner Court of Session pursuant to a petition by a number

5 For a detailed insight into the key judgments of the CJEU concerning the concept of „autonomy“ of EU law, see: Lukić, 2011.

6 Case C-621/18, Wightman v Secretary of State for Exiting the European Union [2018], par. 76. 
of Scottish MPs. The opinion was issued on 10 December 2018, within three months from the day on which the request was filed and prior to the adoption of the EU - UK Withdrawal Agreement in the House of Commons (Garner, 2018).

\subsection{Withdrawal agreement}

Article 50 TEU remains ambiguous in relation to the contents of the withdrawal agreement. As noticed by Craig, it leaves room for a broad spectrum of possibilities in relation to its scope, ranging from a very limited regulation on the cessation of effect of EU law in respect of the withdrawing country to a wideranging regulation of future relations between the EU and the withdrawing country (Craig, 2016: 37-38). Perakis points out to the exact wording of Article 50 (2) TEU, where it is prescribed that the withdrawal agreement sets out "the arrangements" for the withdrawal of a member state, "taking account of the framework for its [referring to the withdrawing country] future relationship with the Union"; Perakis concludes that the terms of the future relationship are not the primary subject matter of the withdrawal agreement, and therefore may but need not be included in it (Perakis, 2019: 40-41). There are also authors, such as Dammann, who argue in favor of a strict interpretation of the permissible scope of withdrawal agreements, which would limit the said scope to terms of withdrawal and prevent the inclusion of provisions on the future relations between the EU and the withdrawing country. Dammann bases his claim on the view that a wider scope of a withdrawal agreement would enable circumvention of terms for conclusion of international agreements by the EU, primarily of unanimity requirements in Art. 218(8) TFEU (Dammann, 2018: 174-175).

The primary purpose of the withdrawal agreement is to prescribe terms of cessation of effectiveness of EU law in respect of the withdrawing country, which needs to include in particular terms of commerce, rights and obligations of individuals, timeline for possible gradual cessation of such effectiveness of EU law, etc.

In the opinion of Perakis, which the author of this paper agrees with, Article 50 TEU bestows upon the Union a best-efforts obligation to achieve an agreement with the withdrawing country, and not a duty to achieve the agreement at any cost (Perakis, 2019: 38).

In view of the explicit reference to Art. 218(3) TFEU included in Art. 50 TEU, it is clear that a withdrawal agreement, once it is concluded, constitutes an international agreement to which the EU is a party and, therefore, in line with Art. 216(2) TFEU, acquires direct effect in the EU legal system, including the EU Member States. 


\subsection{The unfolding of Brexit}

The UK referendum on leaving the EU of 23 June 2016 was not legally binding upon the UK Government, in terms of UK constitutional law. It served the UK Government to learn the will of the electorate in respect of the subject issue (UK Institute for Government, 2020). On 13 March 2017, the result of the referendum was confirmed by the UK Parliament in the form of the Notification of Withdrawal Bill, which was passed by both houses of Parliament and received the Royal Assent on 16 March 2017. The Prime Minister of the UK then addressed the President of the European Council with the Article 50 Notification Letter (Letter of 29 March 2017). That letter triggered the process envisaged by Art. 50 TEU.

A withdrawal agreement was first agreed with the UK Government led by Prime Minister Theresa May in March/April 2019. A total of three extensions of the two-year period following the notification of withdrawal were agreed, the last until 31 January 2020. The withdrawal agreement was revised following the UK elections in the Fall of 2019 and the entry of Boris Johnson into the Prime Minister's office. Eventually, the EU - UK Withdrawal Agreement was agreed on 17 October 2019. The Council enacted a decision on conclusion thereof on 30 January $2020 .{ }^{7}$ The agreement entered into force on 1 February 2020, a day after the end of the period prescribed by Art. 50(3) TEU, as had been extended by the European Council in agreement with the UK. ${ }^{8}$ The Withdrawal Agreement allowed for the possibility that the UK-EU joint committee could extend the transition period by up to two years, provided that agreement was reached prior to 1 July 2020. Failing such agreement, the Withdrawal Agreement explicitly stipulated that the transition period shall end on 31 December 2020, at which point in time EU law shall cease to be applicable in the UK. ${ }^{9}$ A separate declaration, titled the "Political declaration setting out the framework for the future relationship between the European Union and the United Kingdom" $(2020)^{10}$, was agreed by the EU and the UK together with the Withdrawal Agreement.

\subsubsection{The EU-UK Withdrawal Agreement}

The EU-UK Withdrawal Agreement was not necessary for Brexit to take place. The actual unfolding of Brexit emphasises the importance of the issue of the legal nature of the withdrawal agreement. The current dispute over the UK's compliance with the Withdrawal Agreement in respect of the powers conferred upon the UK Government ministers by virtue of the envisaged Internal Market

7 Council Decision 2020/135, 2020

8 The Agreement on the Withdrawal, 2020

9 Articles 126, 127, The Agreement on Withdrawal, 2020

10 Political declaration, OJ L 34, 2020 
Bill, pertinent to trade and state aid in Northern Ireland, challenges the upholding of duties of sincere cooperation and acting in good faith, as the principles of EU law which remain in force in relation to the withdrawing state during the transition period.

The EU-UK Withdrawal Agreement has covered several subject areas. First, it ensured the continuation of rights acquired by the UK and EU citizens (as a result of their exercise of the right of free movement), who started living in the EU or in the UK, respectively, up to the end of the transition period. Such persons and their family members shall be able to continue to live, study, work and travel freely after the transition period ends. For this purpose, recognition of professional qualifications and coordination of social security systems have also been agreed upon. ${ }^{11}$ Second, under the title "Separation issues", the agreement regulates the fate of several specific regulatory regimes: treatment of goods placed on the market prior to the end of the transition period, including the ending of ongoing storage and customs procedures and application of ongoing VAT and excise duties rules; the continuation of protection of certain intellectual property rights, such as trade marks, registered designs, geographical indications, designations of origin, as well as of databases (etc.); winding down of ongoing police and judicial cooperation in criminal matters, as well as of judicial cooperation in civil and commercial matters; the use of data exchanged before the end of the transition period, the finalization of ongoing public procurement procedures, specific Euratom-related issues; applicability of ongoing EU judicial and administrative procedures to the UK; privileges, immunities and other issues relating to the functioning of the institutions, bodies, offices and agencies of the EU. ${ }^{12}$ Third, the agreement spells out a number of institutional arrangements specific to the transitional period, including those relating to EU external action and to fishing opportunities, as well as to the possible extension of the transition period..$^{13}$ Furthermore, the agreement comprises provisions on settlement of financial obligations and on dispute resolution, which shall be examined in greater detail. ${ }^{14}$ Finally, specific protocols have been executed in relation to Northern Island, and the Sovereign Base Areas in Cyprus and Gibraltar. Particularly sensitive was the protocol on Northern Ireland because it represented a major revision of the Withdrawal Agreement originally agreed in March 2019. Instead of the initially devised solution whereby Northern Ireland would have essentially remained part of the Single Market, the final mechanism is based on two principles that may generate conflicts in the future: Northern

11 Articles 9 - 39, The Agreement on Withdrawal, 2020

12 Articles 40 - 125, The Agreement on Withdrawal, 2020

13 Articles 126 - 132, The Agreement on Withdrawal, 2020

14 Articles 133 - 181, The Agreement on Withdrawal, 2020 
Ireland shall be treated as part of the UK customs and VAT area, but most EU customs and VAT rules will remain applicable. At the same time, no tariffs or restrictions will apply to the trade between Northern Ireland and the Republic of Ireland, whereas customs checks will be necessary between Great Britain and Northern Ireland.

The fact that the EU-UK Withdrawal Agreement has not encompassed provisions on the relations between the EU and the UK following the transition period may be regarded as a practical confirmation of the doctrinal position that withdrawal agreements under Art. 50 TEU should not regulate the future relationship between the EU and the withdrawing country. It may, however, in practice increase probability that the future relationship shall not involve certain areas, such as common foreign and security policy, since its conclusion required only a qualified majority under Art. 50(2) TEU, whereas conclusion of an agreement involving common foreign and security policy would require unanimity, under Art. 218(8) TFEU.

Certain authors have argued that dispute resolution in respect to any withdrawal agreement must lie in the hands of the CJEU, once a withdrawal agreement inevitably becomes part of EU law (Perakis, 2019: 42-43, 47). Such a position has only partially been materialized in the EU-UK Withdrawal Agreement. In that instrument, a distinction has been made in its dispute resolution provisions between the general dispute resolution competence of an arbitral panel of the Permanent Court of Arbitration and the specific competence of the CJEU. The former shall be competent to resolve a dispute "regarding the interpretation and application of the provisions of this Agreement." As an exception to that general rule of competence, the CJEU shall be competent to decide a "question of interpretation of a concept of Union law, a question of interpretation of a provision of Union law referred to in this Agreement or a question of whether the United Kingdom has complied with its obligations under Article 89(2) [of the Withdrawal Agreement]." The decision of the CJEU will be binding upon the arbitral panel. ${ }^{15}$ The reference to Art. 89(2) of the Withdrawal Agreement leads to Art. 86 and Art. 87 of that instrument, which prescribe competence of the CJEU for proceedings brought by or against the UK during the transition period, and for proceedings brought by the European Commission against the UK within 4 years after the end of the transition period for failure to fulfil obligations under the Treaties or under Part Four of the Withdrawal Agreement, as well as for failure to comply with a legally binding decision of an EU institution during the transition period. Part Four of the Withdrawal Agreement prescribes the terms of the transition period, including applicability of EU law in relation to the UK, institutional arrangements, specific arrangements relating to the Union's

15 Articles 169, 170, 174, The Agreement on Withdrawal, 2020 
external action and to fishing opportunities, supervision and enforcement of EU law during the transition period, as well as the possibility that the transition period be extended. ${ }^{16}$

\subsubsection{The dispute over the UK Internal Market Bill 2019-2021}

In September 2020, the draft United Kingdom Internal Market Bill 2019-2021 entered the procedure for enactment in Parliament. In its present form, the bill would confer upon UK Government ministers powers that would allow them to unilaterally change the protocol to the EU-UK Withdrawal Agreement that pertains to Northern Ireland. If it is enacted, it would grant the ministers the power to unilaterally decide whether to notify the EU Commission of any government subsidy that could affect the trade of goods in Northern Ireland, as well as whether the requirement for export summary declarations for goods sent from Northern Ireland to the rest of the UK may be waived. On 1 October 2020, the EU Commission started infringement proceedings against the UK, while expressing hope that the dispute would be resolved by way of negotiations (The Guardian, Brexit: EU launches legal action against UK for breaching withdrawal agreement). In essence, the subject provisions purport to enable disapplication of EU law in respect of Northern Ireland, as well as to remove an important part of customs controls between Northern Ireland and the rest of the UK.

In a public statement of 10 September 2020, issued following a session of the EU-UK Joint Committee, the EU Commission declared that "Violating terms of the Withdrawal Agreement would break international law, undermine trust and put at risk the ongoing future relationship negotiations", and noted that "If adopted as proposed, the draft bill would be in clear breach of substantive provisions of the Protocol: Article 5 (3) \& (4) and Article 10 on custom legislation and State aid, including amongst other things, the direct effect of the Withdrawal Agreement (Article 4). In addition, the UK government would be in violation of the good faith obligation under the Withdrawal Agreement (Article 5) as the draft Bill jeopardises the attainment of the objectives of the Agreement" (European Commission, 2020a). On 1 October 2020, the EU Commission sent a letter of formal notice to the UK, stating its position that the UK is in breach of the Withdrawal Agreement and thus commencing a formal infringement process against the UK (European Commission, 2020b).

Regulation of trade in respect of Northern Ireland was a major point of contention throughout the negotiations in respect of the EU-UK Withdrawal Agreement. A blunt violation of the agreed solution by the UK has the potential to substantially

16 Art. 126-132, The Agreement on Withdrawal, 2020 
diminish the scope and depth of the partnership that the two sides will agree upon for the post-transition period.

\section{Consequences of the withdrawal on issues of EU citizenship}

From the very beginning, the cornerstone of EU law have been certain freedoms afforded to citizens of Member States. Formal EU citizenship was introduced by the Maastricht Treaty in 1992. Thereafter, the CJEU further developed the concept and importance on EU citizenship. One of the key developments in the CJEU case-law is perhaps the doctrine whereby the Union citizenship has become more than a mere addition to citizenship of a Member State. Precisely due to the fact that Union citizenship is dependent on citizenship of a Member State, the CJEU has afforded itself the right to review Member State decisions regarding citizenship of an individual on the basis of certain minimum standards that have been developed by the Court itself. The doctrine was promulgated in Rottmann ${ }^{17}$ and more recently confirmed in Tjebbes. ${ }^{18}$

Although the Union citizenship status has not evolved to become independent from Member State citizenship, so that Union citizenship status of citizens of a withdrawing state would be unaffected by that state's withdrawal, its legal and political significance has strengthened the legal relevance of individual rights acquired as result of that status. Considering the great significance of citizenshiprelated rights for lives of individuals (including the right to residence, to work or to study), proper regulation of the acquired rights of Union citizens that may be affected by a withdrawal is a greater challenge than any other institutional or public law issue.

\subsection{Implications of Brexit on citizenship- related rights of $E U$ and $U K$ citizens}

It is estimated that at the beginning of 2019 there were 3.4 million EU MemberState nationals (excluding Irish citizens) living in the UK, as well as 1.2 million UK nationals living in the remainder of the EU (Cîrlig, 2020: 2).

17 Case C-135/08, Janko Rottman v Freistaat Bayern, [2010]; For a detailed analysis of Rottmann, see: Lukić, 2012.

18 Case C-221/17, M.G. Tjebbes and Others v Minister van Buitenlandse Zaken [2019]. Some authors argue that the CJEU case law on citizenship has created a situation of reverse discrimination, whereby citizens of Member States who find themselves in situations lacking intra-EU cross-border dimension are afforded a lower level of protection than those finding themselves in intra-EU cross-border situations (Rakić, 2020). 
During the transition period, most rights based on EU citizenship remain unchanged, with the exception of certain political rights of UK nationals in relation to EU bodies. ${ }^{19}$ The EU-UK Withdrawal Agreement guarantees almost all rights acquired by UK citizens who have resided in the remainder of the EU and of EU citizens who have resided in the UK prior to the end of the transition period for at least five years, based on their exercise of rights arising from the free movement of persons principle. ${ }^{20}$ The rights are guaranteed to the persons who acquired them for their entire lifetime, under conditions prescribed in the Withdrawal Agreement, and to their family members, including future children. While the right of residence of UK nationals in an EU country, existing at the end of the transition period, is guaranteed by the Withdrawal Agreement, the right of such persons to move their residence to another EU country in the future has not been guaranteed by the Withdrawal Agreement (Cîrlig, 2020: 5). The choice of a constitutive system for confirming residence and related rights under the Withdrawal Agreement by the UK has been criticized, mostly as been non-inclusive in respect of vulnerable social groups. Out of the 27 remaining EU Member States, 13 have opted for a declaratory system, while 14 have resorted to a constitutive system, requiring that UK nationals file applications for determination of their status and rights under the Withdrawal Agreement (Cîrlig 2020: 8-14).

After the end of the transition period, EU citizens arriving in the UK and UK citizens arriving in the EU will not benefit from the protection of the Withdrawal Agreement, and will be subject to rules applicable to third-country immigrants, unless the EU and the UK agree on a new mobility regime.

\section{Future partnership between the EU and the UK}

In October 2019, together with the Withdrawal Agreement, the EU and the UK agreed upon the "Political declaration setting out the framework for the future relationship between the European Union and the United Kingdom". According to its introductory provisions, the declaration purports to establish "parameters of an ambitious, broad, deep and flexible partnership across trade and economic cooperation with a comprehensive and balanced Free Trade Agreement at its core, law enforcement and criminal justice, foreign policy, security and defence and wider areas of cooperation." The declaration cites "respect for and safeguarding of human rights and fundamental freedoms, democratic principles, the rule of law and support for non-proliferation" as shared values which should

19 Article 127, The Agreement on Withdrawal, 2020

20 Articles 13 - 15, The Agreement on Withdrawal, 2020 
underpin the future relationship. The fields of future cooperation are outlined in two sections, dealing with economic and security partnership. ${ }^{21}$

As with most other declarations on future intentions (and as suggested in the title), the significance of the declaration is almost entirely political, while the only legal effect thereof may be regarded as an obligation to attempt negotiations on the subject of future relationship in line with the declared intentions, in good faith and on a best-efforts basis. Such obligation was explicitly stipulated in the Withdrawal Agreement as well: the EU and the UK agreed to "use their best endeavours, in good faith and in full respect of their respective legal orders", to take necessary steps to negotiate expeditiously the agreements governing their future relationship referred to in the Political Declaration of 17 October 2019.... ${ }^{22}$

As has been already pointed out, EU rules on voting requirements in respect of conclusion of international agreements with third parties shall, from a practical perspective, influence the scope of the agreement on future relationship. An association agreement, as well as coverage of the area of common foreign and security policy, would require unanimity in accordance with Art. 218(8) TFEU, which may be difficult to attain in respect of the UK in view of the resolve of UK leaders to prevent the application of the free movement of persons principle. Recent CJEU case law confirms the view that there may not need be a unanimity requirement on the part of the EU Member States for the EU to conclude a wideranging free trade agreement with the UK (Hughes, 2018: 15).

EU Member States in the General Affairs Council approved the European Commission's Draft Agreement on the New Partnership with the United Kingdom on 25 February 2020. The document was transmitted to the UK on 18 March 2020. Several rounds of negotiations have taken place since. If it is eventually concluded, the agreement shall represent a blueprint of what any other withdrawing state may expect to end up with in relation to the EU. By the same token, if the two parties fail to reach agreement, the EU will be forced to take a harsh position vis-á-vis interests of EU persons and entities in order to provide a clear lesson to any other Member State which envisages to resort to a nonconsensual withdrawal.

If, however, an agreement on the future relations in respect of trade is not agreed prior to end of transition period, WTO rules shall be applicable to EU-UK trade relations, since both the EU and the UK are WTO members (Hughes 2018: 15).

21 Political declaration setting out the framework for the future relationship between the European Union and the United Kingdom, 2020

22 Article 184, The Agreement on Withdrawal, 2020 
For the UK, the issue of particular concern is the ability of its financial sector to do business in the EU. The financial sector in the UK accounts for between 8 and 12\% of GDP (Peihani, 2018: 89). According to Peihani, the UK financial sector may be able to rely on three basis in order to preserve access to the EU market following Brexit: membership in the European Economic Area (the EEA), reliance on EU legislation that allows access based on equivalence of regulatory terms, and a bespoke trading arrangement, whereby only the membership in the EEA is likely to be able to allow the continuation of a wide market access and passporting rights for UK financial services firms (Peihani, 2018: 93-100). The prospect of a no post-Brexit deal between the EU and the UK seems particularly dire for the financial services industry, since the WTO rules of the EU, which would represent the fallback option, do not allow access to the market for financial services (Peihani, 2018: 103).

\section{Consequences of withdrawal under international law}

The simplest account of the legal effect of Brexit would be to say that it shall mean the cessation of effect of EU law in relation to the UK and to the relations between the UK and the EU, the EU Member States and international organizations, so that the latter would be governed by international law. This account would be, however, only true from a distant perspective, while a closer look would reveal numerous exceptions.

Mutually opposed views exist in academic literature in respect of whether the UK would, by way of succession, continue to be bound by international treaties concluded by the EU during the time the UK was a UK member. An argument in favor of such succession would assume that the EU does not possess legal personality independent from the personalities of its Member States. According to Odermatt, the answer to this question will depend on specific circumstances pertinent to each international treaty (Odermatt 2017: 1056-1059). A similar lack of consensus exists in relation to the fate of mixed agreements, concluded both by the EU and the UK with third parties. Particularly significant, from the economic perspective, is the question of whether the UK shall need to renegotiate its trading relationships with third countries, or it will be able to succeed the preferential trading arrangements of the EU. Some authors, such as Hughes, firmly claim that the UK will lose any preferential status it enjoyed while being represented in the WTO by the EU, so that it would need to negotiate its own arrangements (Hughes, 2018: 15). One solution would certainly be that the EU and the UK agree on a common approach to third states and international organizations (Odermatt, 2017: 1060-1061). 
The thesis put forth by a number of authors, including Cottier, that the UK will be worse off once it finds itself in the situation to negotiate its trading relations via bilateral agreements, seems plausible in view of the relative market size and the resulting bargaining power of the UK vis-à-vis the US, the EU, Japan, etc. (Cottier, 2018: 83-84).

In the area of environmental protection, as concluded by Gehring and Phillips, the UK will most probably need to adhere to EU rules in order to preserve market access for its goods, while at the same time it shall lose the ability to influence EU regulation from within (Gehring, Phillips, 2018: 223-224).

\section{Concluding remarks}

Article 50 TEU, as the sole legal mechanism for withdrawal provided by EU law, affords substantial flexibility to the withdrawal process in general, and to the scope of a possible withdrawal agreement in particular. The unfolding of Brexit thus far has created a number of contentious situations, both at the level of UK constitutional law and in relations between the UK and the EU. While the contentious situations at the level of UK constitutional law remain outside of the scope of this paper, their relevance lies in the tensions they have generated for the UK vis-à-vis the EU. Considering the unfolding of Brexit thus far, it appears that the flexibility of Article 50 TEU has withstood the test of practice and proven to be wisely devised. On the other hand, the deliberately undertaken ongoing steps of the UK Government to breach the Withdrawal Agreement and, consequently, EU law, show that the binding effect of EU law is not a legal phenomenon per se, but rather a direct consequence of the political and value-based significance of the EU for its Member States and their citizens.

The agreed detailed regulation of rights of individual persons (EU nationals residing, working or studying in the UK, and vice versa) in the EU-UK Withdrawal Agreement shows the strength of the phenomenon of acquired rights, despite failures to reach agreement in relation to numerous other areas. Brexit has demonstrated that there is still no supranational EU citizenship, independent and different from Member State citizenship.

The peculiar and complex institutional setup of the EU causes significant issues in respect of the relations of the withdrawing state with the EU and its remaining Member States, third states and international organizations. The fate of international obligations in relation to third parties, acquired prior to withdrawal by the EU, as well as by the withdrawing state together with the EU, by virtue of mixed agreements, remains unclear and thus creates great uncertainty. 
Numerous difficulties, disputes, costs and uncertainties created by Brexit seem to confirm the view that the true essence of the EU lies in a political and valuebased union which aspires to an even stronger unity than the one that exists at present. A withdrawal from such a union is a phenomenon that is difficult to imagine and regulate.

\section{References}

Sources of law and official documents

Agreement on the withdrawal of the United Kingdom of Great Britain and Northern Ireland from the European Union and the European Atomic Energy Community, OJ L 29, 31.1.2020, (7-187).

Case C-135/08, Judgment of 2 March 2010, Janko Rottman v Freistaat Bayern [2010], ECLI:EU:C:2010:104

Case C-621/18, Judgment of 10 December 2018, Wightman v Secretary of State for Exiting the European Union [2018], ECLI:EU:C:2018:999

Case C-221/17, Judgment of 12 March 2019, M.G. Tjebbes and Others v Minister van Buitenlandse Zaken [2019], ECLI:EU:C:2019:189

Council Decision (EU) 2020/135 of 30 January 2020 on the conclusion of the Agreement on the withdrawal of the United Kingdom of Great Britain and Northern Ireland from the European Union and the European Atomic Energy Community, OJ L 29, 31.1.2020, (1-6).

Letter of 29 March 2017 from the UK Prime Minister to the President of European Council - Article 50 Notification Letter, retrieved 30 September 2020 from https://data.consilium.europa.eu/doc/document/XT-20001-2017-INIT/en/pdf;

Political declaration setting out the framework for the future relationship between the European Union and the United Kingdom, OJ L 34, 31.1.2020 (1-16).

TEU - Treaty on the European Union. Consolidated version of the Treaty on European Union

OJ C 326, 26.10.2012, (13-390).

TFEU - Treaty on the Functioning of the European Union. Consolidated version of the Treaty on the Functioning of the European Union OJ C 326, 26.10.2012, (47-390). 
Academic literature, public statements and media reports

Benrath, D. (2018). Bona Fide and Revocation of Withdrawal: How Article 50 TEU Handles the Potential Abuse of a Unilateral Revocation of Withdrawal. European Law Review. 43. (234-248).

Cîrlig, C.C. (2020). EU and UK Citizens' Rights After Brexit. Brussels: European Parliamentary Research Service.

Cottier, T. (2018). Trade Policy in the Age of Populism: Why the New Bilateralism Will Not Work. In: Fitzgerald, O. E., Lein, E. (eds.). Complexity's Embrace: The International Law Implications of Brexit (71-84). Waterloo: Centre for International Governance Innovation.

Craig, P. (2016). Oxford Legal Studies Research Paper No. 45/2016, Brexit: A Drama in Six Acts. https://papers.ssrn.com/sol3/papers.cfm?abstract_id=2807975; Retrieved 30 Sept.2020

Dammann, J. (2018). A Little Bit Brexit? An Analysis of the Rules Governing Post-Withdrawal Treaties. Texas International Law Journal. 53 (2). (153-175).

Daswhood, A. (2013). The United Kingdom in a Re-Formed European Union. European Union Law Review. 38. (737-756).

European Commission (2020a). Statement by the European Commission following the extraordinary meeting of the EU-UK Joint Committee of 10 September 2020; Retrieved 30 Sept. 2020 from https://ec.europa.eu/commission/presscorner/detail/en/statement_20_1607

European Commission (2020b). Withdrawal Agreement: European Commission sends letter of formal notice to the United Kingdom for breach of its obligations. 1 October 2020; https://ec.europa.eu/commission/presscorner/detail/ en/ip_20_1798; Retrieved 1 October 2020

Garner, O. (2018). The ECJ Confirms that Article 50 Notification can be Unilaterally Revoked. Retrieved 30 September 2020 from: http://dcubrexitinstitute. eu/2018/12/the-ecj-confirms-that-article-50-notification-can-be-unilaterallyrevoked/

Gehring, M., Phillips, F.-K. (2018). Brexit and Environmental Law: The Rocky Road Ahead. In: Fitzgerald, O. E., Lein, E. (eds.). Complexity's Embrace: The International Law Implications of Brexit (209-223). Waterloo: Centre for International Governance Innovation.

The Guardian (2020). Brexit: EU launches legal action against UK for breaching withdrawal agreement, 1 October 2020, retreived 1 October 2020 from: https:// 
www.theguardian.com/politics/2020/oct/01/brexit-eu-launches-legal-actionagainst-uk-for-breaching-withdrawal-agreement

Hughes, V. (2018). Brexit and International Trade: One Year after the Referendum. In: Fitzgerald, O. E., Lein, E. (eds.). Complexity's Embrace: The International Law Implications of Brexit ( 9-30). Waterloo: Centre for International Governance Innovation.

UK Institute for Government (2020). Brexit Brief: Article 50, retrieved 30 September 2020 from https://www.instituteforgovernment.org.uk/brexit/brexitbrief-article-50 ;

Lukić, M. (2011). Da li je Evropsko pravo autonomno, samosvojno, unutar ili izvan međunarodnog - šta kriju ključne presude Evropskog suda pravde? [Is European law autonomous, unique, within or outside of the international law - what exactly is hidden behind key judgments of the European Court of Justice?]. In Zbornik radova Harmonizacija zakonodavstva Republike Srbije sa pravom Evropske unije [Harmonization of the legislation of the Republic of Serbia with European Union law] (pp. 145-154). Beograd: IMPP, Hanns Seidel Stiftung.

Lukić, M. (2012). Presuda Rottmann (2010) Povratna veza od statusa građanina EU ka državljanstvu države članice [CJEU Rottmann Judgment (2010) - Feedback effect from EU Citizenship to Member State Nationality]. Pravni život. 12 (4). 535-548.

Lukić, M. (2015). How Long Before Bundle of Treaties Becomes Sovereign? A Legal Perspective on the Choices before the EU, South Eastern Europe and the European Union - Legal Aspects. SEE/EU Cluster of Excellence in European and International Law. 1. 127-137.

Odermatt, J. (2017). Brexit and International Law: Disentangling Legal Orders. Emory International Law Review. 31. (1051-1073).

Peihani, M. (2018). Brexit and Financial Services: Navigating through the Complexity of Exit Scenarios. In: Fitzgerald, O. E., Lein, E. (eds.). Complexity's Embrace: The International Law Implications of Brexit pp. 87-103. Waterloo: Centre for International Governance Innovation.

Perakis, M. (2018). Does the principle of the autonomy of the EU legal order allow for a Member State to revoke the notification of its withdrawal from the EU? . Retrieved 30 September 2020 from https://europeanlawblog.eu/2018/10/31/ does-the-principle-of-the-autonomy-of-the-eu-legal-order-allow-for-a-memberstate-to-revoke-the-notification-of-its-withdrawal-from-the-eu/;

Perakis, M. (2019). Exiting the European Union: Legal Procedure, Dimensions and Implications. Newcastle upon Tyne: Cambridge Scholars Publishing. 
Rakić, B. (2020). Obrnuta diskriminacija u Evropskoj uniji [Reverse discrimination in the European Union]. In Krstić, I, Bajović, V. (eds.) Identitetski preobražaj Srbije: prilozi projektu 2019 - kolektivna monografija [Identity transformation of Serbia: contributions to the project 2019 - a collective monograph] (63-100). Beograd: Univerzitet u Beogradu, Pravni fakultet.

Wyrozumska, A. (2012). Withdrawal from the Union. In Blanke, H.-J., Mangiameli, S. (eds.), The European Union after Lisbon (pp. 343-365). Heidelberg: Springer. 
Др Маја Лукић Радовић,

Ванредни професор Правног факултета,

Универзитет у Београду

\title{
НАПУШТАҢЕ ЕУ - ПОСЛЕДИЦЕ У СКЛАДУ СА ПРАВОМ ЕУ И СА МЕЪУНАРОДНИМ ПРАВОМ
}

\begin{abstract}
Резиме
Члан 50. УЕУ, као једини правни механизам за напуштање ЕУ који пружа право EУ, омогућује значајно висок ниво флексибилности за процес напуштања уопште, и, посебно, за садржинуевентуалног споразума о повлачењу. Имајући у виду начин на који се „Брегзит“ одвијао до сада, чини се да је члан 50. УЕУ издржао тест праксе и доказао се као мудро решење. С друге стране, кораци које Влада Уједињеног Краљевства свесно предузима у правиу кршења закљученог Споразума о напуштању ЕУ и права ЕУ показују да обавезујући карактер права ЕУ није чисто правна појава, већ пре свега непосредна последица политичког и вредносног значаја који ЕУ има за њене чланице и држављане.
\end{abstract}

Детаљно уређење права појединаца - држављана ЕУ који имајупребивалиште, раде или студирају у Уједињеном Краљевству и обратно, садржано у Споразуму о напуштању закљученом између ЕУ и Уједињеног Краљевства, насупрот неуспесима да се постигне сагласност о многим другим питањима, показује снагу феномена стечених личних права. Брегзит је у пракси потврдио да још није настало наднационално грађанско право ЕУ, које би било независно од држављанства неке од држава чланища.

Специфична и сложена институционална структура ЕУ отвара значајна питања на плану односа државе која напушта ЕУ са ЕУ и њеним преосталим чланицама, трећим државама и међународним организацијама. Судбина међународних обавеза према трећим странама, стечених пре напуштања од стране ЕУ, као и од стране државе која напушта ЕУ заједно са ЕУ, на основу мешовитих споразума, остаје нејасна, узрокујући велику правну несигурност.

Бројне тешкоће, спорови, трошкови и неизвесности настали услед Брегзита потврђују ствар да суштина ЕУ лежи у политичком и на вредностима заснованом савезу, који тежи много већем јединству од оног које постоји данас. Напуштање таквог савеза је појава коју је тешко замислити и правно уредити.

Кључне речи: Добровољно напуштање ЕУ, Члан 50. УЕУ, Споразум о напуштању ЕУ, Право ЕУ, Право грађанства ЕУ, Спољни односи државе која се повлачи uз EY. 
